\title{
Effect of prey concentrations and feed training on production of Hoplias lacerdae juvenile
}

\author{
RONALD K. LUZ ${ }^{1}$ and MARIA CÉLIA PORTELLA ${ }^{2}$ \\ ${ }^{1}$ Laboratório de Aquacultura, Universidade Federal de Minas Gerais, \\ Av. Antônio Carlos, 6627, 31270-901 Belo Horizonte, MG, Brasil \\ ${ }^{2}$ Universidade Estadual Paulista/UNESP, Centro de Aquicultura, \\ Via Prof. Paulo Donato Castellane, s/n, 14884-900 Jaboticabal, SP, Brasil
}

Manuscript received on August 7, 2014; accepted for publication on November 25, 2014

\begin{abstract}
The aim of this work was to investigate the effects of daily prey concentration during the first 15 days of active feeding of Hoplias lacerdae larvae, and the juvenile size on the feed training. In the first phase, the larvae received five Artemia nauplii concentrations (P). In the second phase, the juveniles from each treatment were trained to accept formulated diet. Superior growth was related to higher initial daily prey concentrations (900 and 1100 nauplii larvae ${ }^{-1}$ ). During feed training, the growth tendency was similar to that verified in the first phase. The lowest values of specific growth rate (SGR) were registered after the introduction of the semi-moist diet used in the feed training. However, the values of SGR recovered along the experiment and similar rates were found among the treatments. Survival, mortality and cannibalism were similar in the different treatments at the end of both phases. It can be concluded that: the prey concentration affects growth of $H$. lacerdae during the first 15 days of active feeding, and feed training can be initialized with juveniles of about $16 \mathrm{~mm}$ of total length.
\end{abstract}

Key words: Artemia, feeding management, larviculture, formulated diet.

\section{INTRODUCTION}

Studies regarding fish larvae growth and survival are important for aquaculture since the larviculture is characterized by high mortality (Puvanendran and Brown 1999). During the larviculture, food quantity can affect growth (Rabe and Brown 2000, Santos and Luz 2009, Santos et al. 2012), cannibalism (Luz and Zaniboni Filho 2001), and reduce mortality when the optimal level is determined (Lee and Ostrowski 2001), optimizing the food use.

Correspondence to: Ronald Kennedy Luz

E-mail:1uzrk@yahoo.com
Furthermore, for production of juveniles of carnivorous species, it is necessary to develop food strategies that stimulate fish to accept formulated diets in substitution to live preys, process known as weaning, which is generally initiated after some days or weeks after the beginning of the exogenous feeding (Luz et al. 2011). For several carnivorous species, the feed training comprising the gradual transition of feed ingredients has been adopted as a weaning strategy (Kubitza and Lovhin 1997, Moura et al. 2000, Luz et al. 2002, 2011, Luz 2004, Soares et al. 2007). 
The trairão Hoplias lacerdae (Characiformes: Erythrinidae) is a carnivorous fish that exhibits excellent meat taste and good market price. Its larviculture has been studied in our laboratory, and high survival rates were registered when Artemia nauplii were used as live food (Luz and Portella 2002, Luz and Portella 2005a, b). This species does not voluntarily accept formulated feeds (Portella and Dabrowski 2008); however, it is able to accept formulated diet after feed training (Luz et al. 2002, Luz 2004, Salaro et al. 2011) and, once trained, can be adapted to rearing with commercial diet (Luz et al. 2001, Salaro et al. 2003, 2006, 2008, Nogueira et al. 2005), indicating its potential for commercial production.

The aim of this work was to evaluate the effects of prey concentrations during the larviculture on survival and fish growth performance, and the initial juvenile size on the feed training success of $H$. lacerdae.

\section{MATERIALS AND METHODS}

The experiment was carried out in two experimental phases. In the first one different prey concentrations were investigated on juvenile production and in the second phase, we investigated the effect of the juvenile size on fish performance during the feed training. For both phases a completely randomized design was used, with five treatments and four replicates.

Eight-day old $H$. lacerdae larvae $(9.3 \pm 0.3$ $\mathrm{mg}$ and $10.1 \pm 0.3 \mathrm{~mm}$ ) at the onset of exogenous feeding were stocked (30 larvae $\mathrm{L}^{-1}$ ) in 205 -L aquaria equipped with aeration system (dissolved oxygen $>6.5 \mathrm{mg} \mathrm{L}^{-1}$ ). To minimize water temperature variation, the aquaria were randomly distributed inside 10 130-L polyethylene tanks, with controlled temperature (aquaria temperature $=$ $\left.28.7 \pm 1.2^{\circ} \mathrm{C}\right)$.

Five daily Artemia nauplii concentrations were evaluated (300, 500, 700, 900 and 1,100 nauplii larvae ${ }^{-1}$, constituting the treatments $\mathrm{P}_{300}, \mathrm{P}_{500}$,
$\mathrm{P}_{700}, \mathrm{P}_{900}$ and $\mathrm{P}_{1100}$, respectively). These initial concentrations were increased in 50\% every five days. Larvae were fed three times a day at 7:00, 12:00 and 18:00 hours. The Artemia nauplii were hatched in $10 \mathrm{~g}$ of salt $\mathrm{L}^{-1}$ salinity. The aquaria were siphoned daily to take out the wastes, when about $70-80 \%$ of the total volume was renewed.

At the end of the first phase (15 days of active feeding), fish from each treatment were grouped and rearranged for the second phase. The juveniles were then stocked at a density of 10 juveniles $\mathrm{L}^{-1}$ in 2010 -L aquaria and submitted to feed training. This strategy consisted of gradual ingredient transition of mixtures of beef (bovine heart muscle) (B), and extruded commercial diet (D) up to the exclusive use of the commercial diet (Luz et al. 2002). Five diets with different proportions of the ingredients (\%) were used: 20D:80B (diet 1); 40D:60B (diet 2); 60D:40B (diet 3); 80D:20B (diet 4); and 100D (diet 5). The ingredients (dry diet was crumbled in a $<0.5 \mathrm{~mm}$ diameter and the beef was triturated) were mixed up to form a consistent and homogenous mass. The diets were then frozen and small portions were defrosted to be used throughout the day. The diets 1, 2, 3 and 4 were offered for 3 days each, while diet 5 was used for 4 days.

The juveniles were fed ad libitum three times a day. The diets 1, 2, 3 and 4 were passed through a sieve of $1 \mathrm{~mm}$ diameter before being offered. Diet 5 consisted of a commercial extruded dry diet (diameter $<2.8 \mathrm{~mm}$ ). The results of the analysis of the ingredients and the diets (AOAC 1984) used in the feed training are shown in Table I.

During feed training the water temperature was $29.8 \pm 0.6^{\circ} \mathrm{C}$. Each aquarium was supplied with constant aeration (dissolved oxygen $>6.5 \mathrm{mg} \mathrm{L}^{-1}$ ) and a water flow of $12 \mathrm{~L}$ hour $^{-1}$. The aquaria were siphoned to take out the wastes and uneaten feed before the meals.

During both phases, the aquaria were covered with a black canvas to keep complete darkness inside them. The aquaria were uncovered only 
TABLE I

Composition of diets (\% in dry matter) used during the feed training of Hoplias lacerdae juveniles.

\begin{tabular}{ccccccc}
\hline Diets & Crude protein & Ether extract & Crude fiber & Dry matter & Ash & $\begin{array}{c}\text { Gross energy } \\
\left(\mathbf{k c a l ~}^{-1} \mathbf{~}\right.\end{array}$ \\
\hline 1 & 54.23 & 15.62 & 0.6 & 84.24 & 0.91 & $5,638.06$ \\
2 & 51.24 & 14.10 & 1.2 & 86.16 & 0.90 & $5,338.13$ \\
3 & 46.80 & 10.13 & 1.8 & 88.89 & 0.88 & $5,038.19$ \\
4 & 44.14 & 10.13 & 2.4 & 93.60 & 0.87 & $4,738.25$ \\
5 & 43.11 & 7.63 & 3.0 & 99.20 & 0.86 & $4,438.32$ \\
\hline
\end{tabular}

Diet 5 (extruded commercial diet). Guarantee levels \%: Mineral matter $(\max ) 20.00$; calcium $(\max )$ 4.00; phosphorus (min) 1.50; Animal protein (min) 20.00; Vitamins: $A=12000 \mathrm{UI} ; \mathrm{B}_{1}=12.00 \mathrm{mg} ; \mathrm{B}_{2}=34.00 \mathrm{mg}$; $\mathrm{B}_{12}=20.00 \mathrm{mg} ; \mathrm{B}_{6}=17.00 \mathrm{mg} ; \mathrm{C}=510.00 \mathrm{mg} ; \mathrm{D}_{3}=3000 \mathrm{UI} ; \mathrm{E}=145.00 \mathrm{mg} ; \mathrm{K}_{3}=17.00 \mathrm{mg} ;$ Folic acid 6.00 mg; Antioxidant $145.00 \mathrm{mg}$; Choline $2500.00 \mathrm{mg}$; $\mathrm{Cu}=6.00 \mathrm{mg}$; $\mathrm{Co}=1.50 \mathrm{mg}$; $\mathrm{Fe}=70.00 \mathrm{mg} ; \mathrm{I}=1.50 \mathrm{mg}$; $\mathrm{Mn}=12.00 \mathrm{mg} ; \mathrm{Se}=0.35 \mathrm{mg} ; \mathrm{Zn}=35.00 \mathrm{mg}$; Niacin $12.00 \mathrm{mg}$; Inositol $350.00 \mathrm{mg}$; Phantotenic acid 70.00 $\mathrm{mg}$; growth promoter $=60.00 \mathrm{mg}$. Beef composition (\% dry matter): Crude protein 71.00; ether extract 30.03; fiber matter 0.00; moisture 28.27; ash 0.96; gross energy 5,938 kcal kg-1.

for daily handling (feeding and cleaning). The pH was measured every three days, while total ammonia was measured once a week, always before the first meal of the day.

At the end of each experimental phase, survival rate, mortality (considering dead individuals taken out of aquarium intact), and apparent cannibalism (calculated by the number of individuals that disappeared during the experiments) were calculated. Total length (mm) and individual wet weight $(\mathrm{mg})$ were evaluated every five days. Samples of 10 animals of each aquarium were taken, anesthetized and killed in cold water for biometric evaluations. The specific growth rate $(\mathrm{SGR})$ was calculated as $\mathrm{SGR}=100 \times\left(\ln \mathrm{W}_{\mathrm{f}}-\ln \right.$ $\left.\mathrm{W}_{\mathrm{i}}\right) / \Delta t$, considering $\Delta t$ the time interval (in days) between the measurements.

At the end of the feed training phase (31 days of active feeding), the juveniles were classified into four size classes: $<2.5 \mathrm{~cm}$ (Class I); $2.6>3.0 \mathrm{~cm}$ (Class II); $3.1>3.5 \mathrm{~cm}$ (Class III) and $>3.6 \mathrm{~cm}$ (Class IV).

The results of the two experimental phases were analyzed by one-way ANOVA, and Tukey's test at a $5 \%$ probability level. The survival, mortality and cannibalism rates, and SGR data were arcsine transformed but only the percentage results are presented. All statistical analyses were performed using the SAS/STAT software version 6.12.

\section{RESULTS}

In the two experimental phases the water $\mathrm{pH}$ values were stable, around $7.7 \pm 0.2$. Total ammonia levels were significantly affected by prey concentrations $(P<0.05)$. The values increased in direct proportion to prey concentrations $\left(\mathrm{P}_{300}=0.39 \mathrm{mg} \mathrm{L}^{-1} ; \mathrm{P}_{500}=0.59\right.$ $\mathrm{mg} \mathrm{L}^{-1} ; \mathrm{P}_{700}=0.65 \mathrm{mg} \mathrm{L}^{-1} ; \mathrm{P}_{900}=0.99 \mathrm{mg} \mathrm{L}^{-1} ; \mathrm{P}_{1100}=$ $\left.1.18 \mathrm{mg} \mathrm{L}^{-1}\right)$. However, during the feed training, the ammonia levels were lower than $0.11 \mathrm{mg} \mathrm{L}^{-1}$.

Survival and apparent cannibalism rates were not affected by the different treatments in the two experimental phases (Table II). Mortality rate was higher in $\mathrm{P}_{500}$ in the first phase.

After five days of active feeding, lower weight $(P<0.05)$ was registered in $\mathrm{P}_{300}$ treatment, while the highest values were found in $\mathrm{P}_{900}$ and $\mathrm{P}_{1100}$ treatments (Table III). After 15 days of active feeding, the same trend was maintained ( $P$ $>0.05)$ and the $\mathrm{P}_{500}$ and $\mathrm{P}_{700}$ treatments presented intermediate results. Growth during the feed training followed the same tendency, but the highest prey concentration resulted in higher weight $(P<0.05)$. 
TABLE II

Survival, mortality and apparent cannibalism rates ( \pm standard deviation) of Hoplias lacerdae juvenile at the end of the two experimental phases.

\begin{tabular}{lccccc}
\hline & $\mathbf{P}_{\mathbf{3 0 0}}$ & $\mathbf{P}_{\mathbf{5 0 0}}$ & $\mathbf{P}_{\mathbf{7 0 0}}$ & $\mathbf{P}_{\mathbf{9 0 0}}$ & $\mathbf{P}_{\mathbf{1 0 0}}$ \\
\hline & \multicolumn{5}{c}{ First phase (Different prey concentrations) } \\
\cline { 2 - 6 } Survival (\%) & $98.0 \pm 1.3$ & $96.1 \pm 2.3$ & $98.1 \pm 1.9$ & $95.1 \pm 1.8$ & $96.1 \pm 2.3$ \\
Mortality (\%) & $1.9 \pm 1.3^{\mathrm{ab}}$ & $3.6 \pm 2.5^{\mathrm{b}}$ & $0.6 \pm 0.8^{\mathrm{a}}$ & $3.4 \pm 2.5^{\mathrm{ab}}$ & $2.2 \pm 0.5^{\mathrm{ab}}$ \\
Cannibalism (\%) & 0.0 & $0.2 \pm 0.4$ & $1.5 \pm 1.5$ & $1.7 \pm 2.4$ & $1.9 \pm 2.5$ \\
\hline \multicolumn{7}{c}{ Second phase (Feed training) } \\
\hline Survival (\%) & $90.3 \pm 8.6$ & $90.6 \pm 2.1$ & $89.2 \pm 9.5$ & $93.7 \pm 4.4$ & $88.2 \pm 5.7$ \\
Mortality (\%) & $2.8 \pm 3.2$ & $5.0 \pm 1.4$ & $2.8 \pm 3.4$ & $1.5 \pm 1.2$ & $3.4 \pm 1.6$ \\
Cannibalism (\%) & $6.8 \pm 6.6$ & $4.4 \pm 2.6$ & $7.8 \pm 7.2$ & $4.6 \pm 3.6$ & $8.4 \pm 5.3$ \\
\hline
\end{tabular}

Means followed by different letters in the row differ by Tukey's test $(P<0.05)$.

TABLE III

Weight and total length ( \pm standard deviation) of Hoplias lacerdae juveniles during the experiment.

\begin{tabular}{|c|c|c|c|c|c|}
\hline & $\mathbf{P}_{300}$ & $\mathbf{P}_{500}$ & $\mathbf{P}_{700}$ & $\mathbf{P}_{900}$ & $P_{1100}$ \\
\hline & \multicolumn{5}{|c|}{ First phase (Different prey concentrations) } \\
\hline & \multicolumn{5}{|c|}{ Weight $(\mathrm{mg})$} \\
\hline 5 days of active feeding & $18.7 \pm 1.6^{\mathrm{c}}$ & $25.2 \pm 1.1^{\mathrm{b}}$ & $27.5 \pm 1.6^{\mathrm{b}}$ & $31.7 \pm 0.4^{\mathrm{a}}$ & $31.1 \pm 1.4^{\mathrm{a}}$ \\
\hline 10 days of active feeding & $30.1 \pm 1.6^{\mathrm{d}}$ & $43.5 \pm 2.5^{\mathrm{c}}$ & $52.2 \pm 3.6^{\mathrm{b}}$ & $63.8 \pm 2.7^{\mathrm{a}}$ & $66.2 \pm 2.8^{\mathrm{a}}$ \\
\hline \multirow[t]{2}{*}{15 days of active feeding } & $52.7 \pm 2.7^{\mathrm{d}}$ & $76.3 \pm 6.5^{\mathrm{c}}$ & $101.9 \pm 9.0^{\mathrm{b}}$ & $121.9 \pm 6.8^{\mathrm{a}}$ & $127.2 \pm 13.7^{\mathrm{a}}$ \\
\hline & \multicolumn{5}{|c|}{ Length $(\mathrm{mm})$} \\
\hline 5 days of active feeding & $12.3 \pm 0.3^{\mathrm{c}}$ & $13.8 \pm 0.1^{\mathrm{b}}$ & $14.1 \pm 0.1^{\mathrm{b}}$ & $14.7 \pm 0.2^{\mathrm{a}}$ & $14.6 \pm 0.1^{\mathrm{a}}$ \\
\hline 10 days of active feeding & $15.0 \pm 0.2^{\mathrm{d}}$ & $16.5 \pm 0.2^{\mathrm{c}}$ & $17.1 \pm 0.1^{\mathrm{b}}$ & $18.8 \pm 0.4^{\mathrm{a}}$ & $18.5 \pm 0.2^{\mathrm{a}}$ \\
\hline \multirow[t]{3}{*}{15 days of active feeding } & $16.9 \pm 0.3^{\mathrm{d}}$ & $18.6 \pm 0.2^{\mathrm{c}}$ & $20.3 \pm 0.2^{\mathrm{b}}$ & $21.8 \pm 0.2^{\mathrm{a}}$ & $22.1 \pm 0.9^{\mathrm{a}}$ \\
\hline & \multicolumn{5}{|c|}{ Second phase (Feed training) } \\
\hline & \multicolumn{5}{|c|}{ Weight (mg) } \\
\hline 20 days of active feeding & $68.3 \pm 4.7^{\mathrm{d}}$ & $97.3 \pm 12.6^{\mathrm{c}}$ & $116.4 \pm 8.6^{\mathrm{bc}}$ & $130.9 \pm 15.5^{\mathrm{b}}$ & $154.1 \pm 9.6^{\mathrm{a}}$ \\
\hline 25 days of active feeding & $86.4 \pm 11.2^{\mathrm{c}}$ & $129.1 \pm 3.0^{\mathrm{b}}$ & $163.2 \pm 9.4^{\mathrm{a}}$ & $173.1 \pm 23.7^{\mathrm{a}}$ & $184.9 \pm 12.1^{\mathrm{a}}$ \\
\hline \multirow[t]{2}{*}{31 days of active feeding } & $116.9 \pm 8.6^{\mathrm{d}}$ & $172.8 \pm 2.1^{\mathrm{c}}$ & $230.4 \pm 25.8^{\mathrm{b}}$ & $242.5 \pm 26.5^{\mathrm{ab}}$ & $281.2 \pm 25.2^{\mathrm{a}}$ \\
\hline & \multicolumn{5}{|c|}{ Length $(\mathrm{mm})$} \\
\hline 20 days of active feeding & $18.6 \pm 0.5^{\mathrm{d}}$ & $20.3 \pm 0.7^{\mathrm{c}}$ & $21.3 \pm 0.9^{\mathrm{bc}}$ & $22.4 \pm 0.6^{\mathrm{ab}}$ & $23.4 \pm 0.2^{\mathrm{a}}$ \\
\hline 25 days of active feeding & $20.6 \pm 0.6^{\mathrm{c}}$ & $23.3 \pm 0.8^{\mathrm{b}}$ & $24.8 \pm 0.7^{\mathrm{ab}}$ & $25.1 \pm 1.2^{\mathrm{a}}$ & $25.4 \pm 0.6^{\mathrm{a}}$ \\
\hline 31 days of active feeding & $22.4 \pm 1.1^{\mathrm{c}}$ & $25.6 \pm 0.8^{\mathrm{b}}$ & $27.4 \pm 1.1^{\mathrm{ab}}$ & $27.8 \pm 0.8^{\mathrm{a}}$ & $29.4 \pm 0.9^{\mathrm{a}}$ \\
\hline
\end{tabular}

Means followed by different letters in the row differ by Tukey's test $(P<0.05)$.

The variations observed in total length during the first phase were similar to that observed for weight (Table III). At the end of second phase (feed training), animals from $\mathrm{P}_{900}$ and $\mathrm{P}_{1100}$ showed higher total length $(P<0.05)$, while fish from $\mathrm{P}_{300}$ were the smallest.

At the end of the feed training, $H$. lacerdae juveniles reared on the lower prey concentrations $\left(\mathrm{P}_{300}\right)$ during the first phase, comprised $74 \%$ in Class I $(<2.5 \mathrm{~cm})$ (Fig. 1). In the other treatments there was predominance of individuals from Class II $(2.6>3.0 \mathrm{~cm})$. Higher occurrence of bigger animals $(3.1>3.5 \mathrm{~cm})$ was achieved in $\mathrm{P}_{1100}$ treatment.

During the first interval between measurements (1-5 days of active feeding) the SGR was lower $(P<0.05)$ in the fish from $\mathrm{P}_{300}\left(13.9 \%\right.$ day $\left.^{-1}\right)$ (Fig. 2), while the ones from $\mathrm{P}_{900}$ and $\mathrm{P}_{1100}$ exhibited higher and similar $(P>0.05)$ values $(24.5$ and $24.2 \%$ day ${ }^{-1}$, respectively). The $\mathrm{P}_{500}$ and $\mathrm{P}_{700}$ treatments 


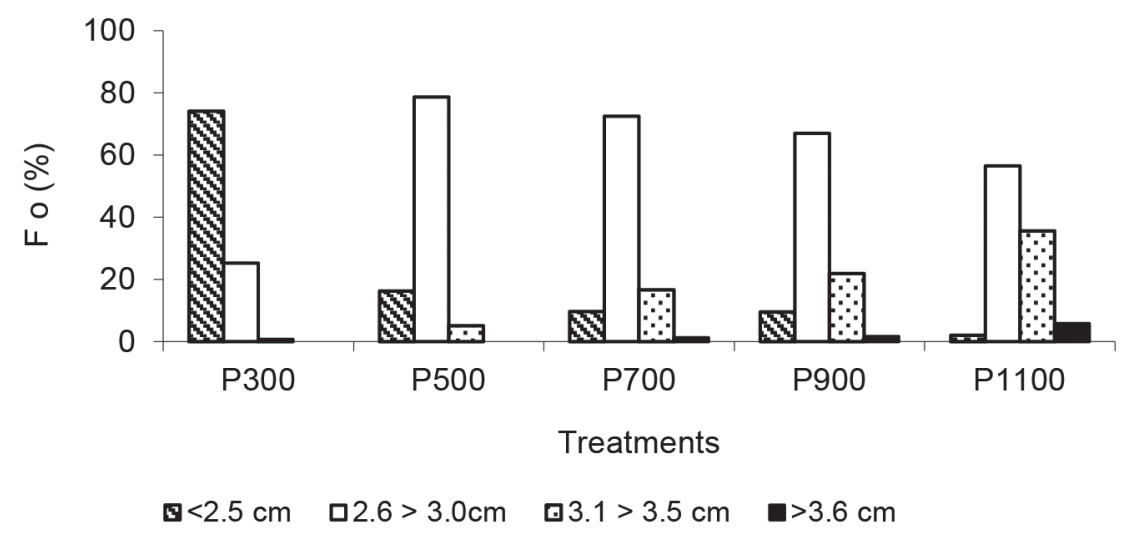

Figure 1 - Frequency of occurrence (Fo) of Hoplias lacerdae juveniles in different size classes at the end of the experiment.

were intermediate. In the next period (6-10 days of active feeding), a decrease of the SGR was registered in all treatments, with similar rates $(P>$ 0.05) for fish from $\mathrm{P}_{1100}, \mathrm{P}_{900}$ and $\mathrm{P}_{700}$ treatments. However, between 11-15 days of active feeding, significant differences among the treatments were not found $(P>0.05)$. After the beginning of the feed training, the SGR of the juveniles decreased dramatically, and similar rates in all treatments $(P>$ $0.05)$ were found. However, fish recovered growth and no statistical differences were observed among all treatments up to the end of the experiment.

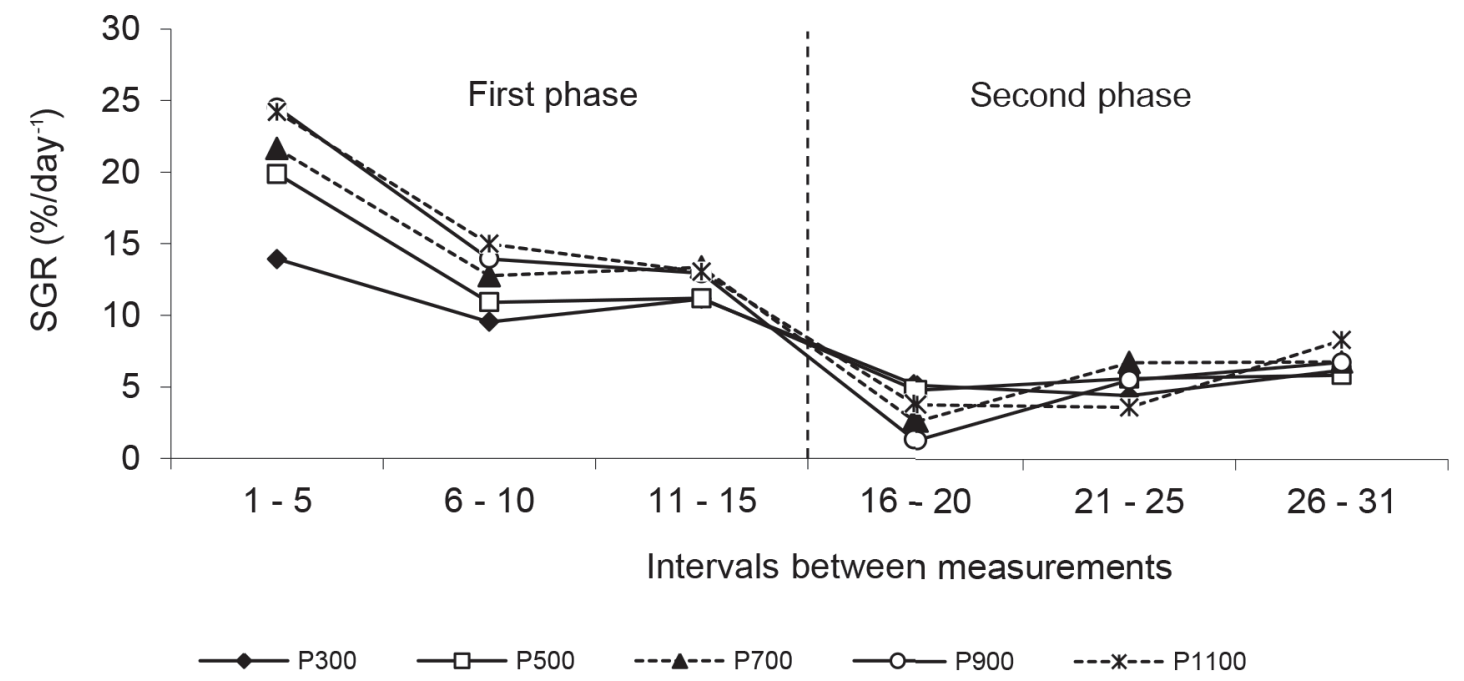

Figure 2 - Mean values of specific growth rate (SGR) $\left(\%\right.$ day $\left.^{-1}\right)$ of Hoplias lacerdae larvae and juveniles under different prey concentrations (first experimental phase) and feed training (second experimental phase).

DISCUSSION

The higher the prey concentration, the higher was the level of ammonia registered in the first phase. However, no mortality of $H$. lacerdae was related. Larvae and juveniles of this species seem to be resistant to high ammonia levels $\left(2.01 \mathrm{mg} \mathrm{L}^{-1}\right)(\mathrm{Luz}$ and Portella 2005a). During the feeding training the use of continuous water flow contributed to maintain the ammonia at lower levels, even when excess of food was used. 
The high survival rates achieved at the end of both experimental phases showed that the rearing protocol applied (i.e. prey concentrations, dark environment, stock density, and the semi-moist diets used for feed training) was adequate for the production of $H$. lacerdae juvenile, minimizing the occurrence of cannibalism. According to Luz and Zaniboni Filho (2001), one of the factors that induce cannibalism during larviculture is insufficient food quantity. Moreover, the weaning to dry diets, which plays an important role in larvae survival, especially for carnivorous fish (Lee and Ostrowski 2001) was also successful in the present study.

The different prey concentrations did not affect $H$. lacerdae survival during larviculture. Similar results were found with other freshwater fish larvae that present cannibalistic behavior such as Pimelodus maculatus (Luz and Zaniboni Filho 2001), Pseudoplatystoma corruscans, and Lophiosilurus alexandri (Santos and Luz 2009) indicating that this variable, within a certain range, is not decisive for the survival of these species.

The high survival rates of $H$. lacerdae during the feed training are similar to previous study carried out juveniles of this species $(2.9 \mathrm{~cm}$ total length $-96 \%$ of survival) (Luz et al. 2002), showing the good acceptance of formulated diets for this species.

The prey concentrations have an influence on the growth of H. lacerdae. It can be expected, up to a certain point, that different prey concentrations may have an effect upon fish growth, especially in the first days of active feeding, as observed for Sebastes spp. (Laurel et al. 2001), Acipenser transmontanus (Deng et al. 2003), Paralichthys olivaceus (Dou et al. 2003), P. costatus and L. alexandri (Santos and Luz 2009), and Rhinelepis aspera (Santos et al. 2012). However, in another species like P. maculatus (Luz and Zaniboni Filho 2001), and P. corruscans (Santos and Luz 2009) this effect was not detected. This fact can be related to intrinsic characteristics of the different species, and the range of prey concentrations used. Feed excess ( $\mathrm{P}_{1100}$ treatment) did not improve growth during the first 15 days of active feeding. The use of levels above animal's assimilation capacity can cause a faster pass by digestive tract (Werner and Blaxter 1980), or water quality deterioration if the food excess is not eaten. The inefficiency of excessively high prey concentrations was registered for Gadus morhua larvae fed up to 16000 organisms $\mathrm{L}^{-1}$ (Puvanendran and Brown 1999), Perca fluviatilis larvae fed up to 12000 rotifers $\mathrm{L}^{-1}$ (Wang and Eckmann 1994), and P. corruscans larvae fed up to 900 Artemia nauplii larvae ${ }^{-1}$ (Santos and Luz 2009). In these works, higher or similar growth was reached with lower prey concentrations, of 4000 organisms L ${ }^{-1}, 6000$ rotifers L $L^{-1}$, and 300 Artemia nauplii larvae ${ }^{-1}$, respectively.

The weight growth during the feed training followed the same tendency verified in the previous phase when different prey concentrations were used. It is interesting to note that at the end of the first phase, the larvae weight from $\mathrm{P}_{900}$ and $\mathrm{P}_{1100}$ treatments were statistically similar, but at the end of the feed training the slight numeric difference in the first phase increased in the second, despite of statistical similarity. However, the apparent advantage of heavier individuals by the end of the feed training would not necessarily lead to greater profits on animal selling, once the prices of $H$. lacerdae juveniles are given according to their total length. Furthermore, when increasing the prey concentrations in the first phase the water quality got worse. Thus, the initial rearing with prey concentrations of 900 Artemia nauplii larvae $^{-1}$ can result in an economy on live food costs, once Artemia can represent one of the most expense items of variable production costs, as observed in Piaractus mesopotamicus larviculture (47\% of variable costs) (Jomori et al. 2005).

Fast acceptance of the inert diets by $H$. lacerdae juveniles was observed in all initial prey concentration treatments, including fish as small 
as $16 \mathrm{~mm}$ of total length $\left(\mathrm{P}_{300}\right)$. The fish size at the beginning of the feed training is an important variable, seeing that the bigger the fish, the better is the acceptance of the formulated diet (Kubitza and Lovshin 1997, Moura et al. 2000). In fact, this has already been demonstrated in a previous study for H. lacerdae (Luz 2004). This author registered that feed training starting in animals with $18.4 \pm 0.7$ and $20.7 \pm 0.6 \mathrm{~mm}$ improved the inert diet acceptance in comparison to animals that received the feed training with lower total length.

At the end of the feed training, fish size was relatively uniform in all treatments, but some big and small animals were observed in all treatments. However, size heterogeneity can favor the occurrence of cannibalism in this species, as observed when juveniles of 2.9 and $4.6 \mathrm{~cm}$ of total length were stocked in the same tank (Luz et al. 2000). To avoid this situation, at the end of the feed training, a classification is necessary to initiate the next production phase.

In the present study, H. lacerdae larvae showed higher SGR during the early life followed by a tendency of decreasing rates as the animal grows, a pattern also registered with L. alexandri (Santos and Luz 2009), and R. aspera larvae fed with different prey concentrations (Santos et al. 2012). However, a more drastic drop in the SGR was found after the introduction of semi-moist diet (beginning of the feed training), reflecting the period of feed transition and the reluctance of fish to accept and ingest the new source of food. According to Duray and Bagarinao (1984), this fact can be attributed to adaptation stress. Interestingly, fish from all treatments showed similar behavior, and growth recovery was verified after a few days, similarly to what was observed in Gadus morhua larvae fed with different prey concentrations, after three weeks of rearing (Puvanendran and Brown 1999).

In short, the knowledge of the adequate prey concentrations during larviculture is important to achieve better growth and to save on production costs. Besides, the ideal prey concentrations lead to a more efficient production system, diminishing the rearing cycle and enabling the use of the facilities for successive larvicultures. H. lacerdae juveniles with at least $16 \mathrm{~mm}$ of total length are ready to be trained to accept formulated diets. Another application of such knowledge is the possibility of juvenile growth manipulation during the production program, according to the market demand.

\section{ACKNOWLEDGMENTS}

This research received support from Coordenação de Aperfeiçoamento de Pessoal de Nível Superior (CAPES/Brazil) by means of a scholarship to Ronald Kennedy Luz.

\section{RESUMO}

O objetivo deste trabalho foi avaliar o efeito de diferentes concentrações de presa durante os primeiros 15 dias de alimentação ativa de larvas de Hoplias lacerdae e o tamanho inicial dos juvenis no condicionamento alimentar. Na primeira fase as larvas receberam cinco concentrações de náuplios de Artemia (P). Na segunda fase, os juvenis de cada tratamento foram condicionados a aceitar dieta formulada. Maior crescimento foi verificado nas mais altas concentrações iniciais diárias de presa mais altas (900 e 1.100 náuplios por larva). Durante o condicionamento alimentar a tendência de crescimento foi semelhante à registrada na primeira fase. As taxas de crescimento específico (TCE) mais baixas foram verificadas com o início do fornecimento da dieta semi-úmida usada no condicionamento alimentar. No entanto, os valores das TCE mostraram recuperação no decorrer do trabalho e valores similares foram encontrados entre os tratamentos. A sobrevivência, mortalidade e canibalismo foram semelhantes entre os diferentes tratamentos ao final das duas fases. Pode-se concluir que: a concentração de presas afeta o crescimento de H. lacerdae durante os primeiros 15 dias de alimentação ativa e o condicionamento alimentar pode ser iniciado em juvenis com comprimento total de aproximadamente $16 \mathrm{~mm}$. 
Palavras-chave: Artemia, manejo alimentar, larvicultura, dieta formulada.

\section{REFERENCES}

AOAC - Association of OfFicial Analytical Chemists. 1984. Official methods of analysis. Arlington: AOAC, $1097 \mathrm{p}$.

Deng DF, Koshio S, Yokoyama S, Bai SC, SHaO QJ, CUI YB AND HUNG SSO. 2003. Effects of feeding rate on growth performance of white sturgeon (Acipenser transmontanus) larvae. Aquaculture 217: 589-598.

Dou S, Masuda R, TANaKa M and Tsukamoto K. 2003. Identification of factors affecting the growth and survival of the settling Japanese flounder larvae, Paralichthys olivaceus. Aquaculture 218: 309-327.

DURAY MN AND BAGARINAO T. 1984. Weaning of hatcherybred milkfish larvae from live food to artificial diets. Aquaculture 41: 325-332.

JOMORI RK, CARNEIRO DJ, MARTINS MIEG AND PORTELlA MC. 2005. Economic evaluation of Piaractus mesopotamicus juvenile production in different rearing systems. Aquaculture 243: 175-183.

KUBITZA F AND LOVSHIN LL. 1997. Effects of initial weight and genetic strain on feed training largemouth bass Micropterus salmoides using ground fish flesh and freeze dried krill as starter diets. Aquaculture 148: 179-190.

LAUREL BJ, BROWN JA AND ANDERSON R. 2001. Behaviour, growth and survival of redfish larvae in relation to prey availability. J Fish Biol 59: 884-901.

LEE CS AND OSTROWSKI AC. 2001. Current status of marine finfish larviculture in the United States. Aquaculture 200: 89-109.

LUZ RK. 2004. Aspectos da larvicultura do trairão Hoplias lacerdae: manejo alimentar, densidade de estocagem e teste de exposição ao ar. (Doutorado em Aquicultura) Universidade Estadual Paulista Júlio de Mesquita Filho, Jaboticabal, Brasil, $120 \mathrm{f}$.

LUZ RK AND PORTELLA MC. 2002. Larvicultura de trairão (Hoplias lacerdae) em água doce e água salinizada. $\mathrm{R}$ Bras Zootec 31: 829-834.

LuZ RK AND PorTella MC. 2005a. Diferentes densidades de estocagem na larvicultura do trairão Hoplias lacerdae. Acta Sci 27: 95-101.

LUZ RK AND PORTELla MC. 2005b. Freqüência alimentar na larvicultura do trairão (Hoplias lacerdae). R Bras Zootec 34: 1442-1448.

LUZ RK, SALARO AL, SOUTO EF, OKANO WY AND LIMA RR. 2002. Condicionamento alimentar de alevinos de trairão (Hoplias cf. lacerdae). R Bras Zootec 31: 1881-1885.

LuZ RK, SAlaro AL, SOUTO EF, ReIS A AND SAKABE R. 2001. Desenvolvimento de alevinos de trairão com dietas artificiais em tanques de cultivo. R Bras Zootec 30: 1159-1163.

LuZ RK, SALARO AL, SOUTO EF AND ZANIBONI FILHO E. 2000. Avaliação de canibalismo e comportamento territorial de alevinos de trairão (Hoplias lacerdae). Acta Sci 22: 465-469.
LuZ RK, SANTOS JCE, Pedreira MM And TeIXeIra EA. 2011 Effect of water flow rate and feed training on "pacamã" (Siluriforme: Pseudopimelodidae) juvenile production. Arq Bras Med Vet Zootec 63: 973-979.

LUZ RK AND ZANIBONI FILHO E. 2001. Utilização de diferentes dietas na primeira alimentação do mandi-amarelo (Pimelodus maculatus, Lacépède). Acta Sci 23: 483-489.

MOURA MAM, KUBITZA F AND CYRINO JEP. 2000. Feed training of peacock bass (Cichla sp.). R Bras Biol 60: 645-654.

Nogueira GCCB, SAlaro AL, Luz RK, JuANON JAS, LAMBERTUCCI DM, SALERNO RA, SAKABE R AND ARAÚJO WAG. 2005. Desempenho produtivo de juvenis de trairão (Hoplias lacerdae) alimentados com rações comerciais. R Ceres 52: 401-497.

PorTella MC AND DABRowsKi K. 2008. Diets, physiology, biochemestry and digestive tract development of freshwater fish larvae. In: CYRINO JCE, BUREAU D AND KAPOR BG (Eds), Feeding and digestive functions of fishes. $1^{\text {st }} \mathrm{ed}$. Enfield, NH, USA: Science Publishers, Inc., p. 227-279.

PUVANENDRAN V AND BROWN JA. 1999. Foraging, growth and survival of Atlantic cod reared in different prey concentrations. Aquaculture 175: 77-92.

RABE J AND BROWN JA. 2000. A pulse feeding strategy for rearing larval fish: an experiment with yellowtail flounder. Aquaculture 191: 289-302.

Salaro AL, Luz RK, Nogueira GCC, Reis A, SAKabe R AND LAMBERTUCCI DM. 2003. Diferentes densidades de estocagem na produção de alevinos de trairão (Hoplias cf. lacerdae). R Bras Zootec 32: 1033-1036.

SALARO AL, LUZ RK, SAKABE R, KASAI RYDAND LAMBERTUCCI DM. 2008. Níveis de arraçoamento para juvenis de trairão (Hoplias lacerdae). R Bras Zootec 37: 967-970.

SALARO AL, LuZ RK, ZUANON JAS, SiROL RN, SAKABE R, ARAÚJO WAG AND SoUTO EF. 2006. Desenvolvimento de alevinos de trairão (Hoplias lacerdae) na ausência de luz. Acta Sci 28: 47-50.

Salaro AL, Tavares MM, Chaves W, Campelo DaV, ZUANON JAS AND LUZ RK. 2011. Feed training of juvenile giant trahira under different light intensities. R Bras Zootec 40: 2290-2293.

SANTOS JCE AND LUZ RK. 2009. Effect of salinity and prey concentrations on Pseudoplatystoma corruscans, Prochilodus costatus and Lophiosilurus alexandri larviculture. Aquaculture 287: 324-328.

SANTOS JCE, PEDREIRA MM AND LUZ RK. 2012. The effect of stocking density, prey concentration and feeding on Rhinelepis aspera (Spix \& Agassiz, 1829) (Pisces: Loricariidae) larviculture. Acta Sc 34: 133-139.

SoARes EC, Pereira-Filho M, Roubach R AND Silva RCS 2007. Condicionamento alimentar no desempenho zootécnico do tucunaré. R Bras Eng Pesca 2: 35-48.

WANG N AND ECKMANN R. 1994. Effects of temperature and food density on egg defvelopment, larval survival and growth of pech (Perca fluviatilis L.). Aquaculture 22: 323-333.

WERNER RG AND BLAXTER JHS. 1980. Growth and survival of larval herring (Clupea harengus) in relation to prey density. Can J Fish Aquatic Sci 37: 1063-1069. 